\title{
AN AGRO-TECHNOLOGICAL CHARACTERIZATION OF SOUTH-EASTERN EUROPEAN BROOMCORN LANDRACES
}

\author{
Vladimir Sikora $^{1, *}$, Vera Popovic ${ }^{1 *}$, Miroslav Zoric ${ }^{1}$, Dragana Latkovic ${ }^{2}$, Vladimir Filipovic ${ }^{3}$ \\ Mladen Tatic ${ }^{1}$ and Jela Ikanovic ${ }^{4}$ \\ ${ }^{1}$ Institute of Field and Vegetable Crops, 21000 Novi Sad, Serbia; ${ }^{2}$ University of Novi Sad, Faculty of Agriculture, \\ 21000 Novi Sad, Serbia; ${ }^{3}$ Institute for Medicinal Plant Research Dr Josif Pancic, 11000 Belgrade, Serbia; ${ }^{4}$ University \\ of Belgrade, Faculty of Agriculture, 11000 Zemun-Belgade, Serbia. \\ *Corresponding author's e-mail: vladimir.sikora@nsseme.com, bravera@eunet.rs
}

\begin{abstract}
Comprehensive overview of the extent genetic diversity in South-East European landrace collection was estimated regard broadening of broomcorn (Sorghum bicolor [L]. Moench) germplasm variability. In a long-term field trials 28 accessions were analyzed to determine variability of agronomic (unthreshed panicle weight UTP, threshed panicle weight TRP, grain yield per panicle SWG and threshed panicle ratio RAN), morphological (plant height PHG, stalk height SHG, panicle length PLG, peduncle length PDL, flag leaf sheath length LSL and panicle exsertion PEX) and technological (fiber length FLG, fiber number per panicle NOP and fiber fineness FFI) traits. By all obtained results combining over univariate and multivariate analysis, the study showed significant variability over traits, so the examined landraces will be included in existing broomcorn germplasm. Accessories with valuable quantitative and qualitative characters can significantly contribute to improvement of new bred cultivars and broadening germplasm diversity. Three years field experiment showed significant positive correlations between PHG-SHG, PDL-PEX and UTP-SWG and significant negative correlations between PDL-FLG and SWG-RAN. The performance of examined landraces were generally within the ambit of broomcorn germplasm variability, but several accessions with the extreme trait profile for yield components and panicle quality will be useful as parents in the breeding process.
\end{abstract}

Keywords: Broomcorn, landraces, panicle quality, technological traits, variability.

\section{INTRODUCTION}

Sorghum is considered as one of the most important plant species worldwide based on production and utilization. It is mainly used as human food, animal feed, building material, fencing, or for brooms (Rooney and Waniska, 2000; Abubaker et al., 2014). Cultivated sorghum in Europe are represented by agronomic types or forms such as grain sorghum, sweet sorghum, sudan grass and broomcorn (Berenji and Dahlberg, 2004). Harlan and de Wet (1972) classified cultivated sorghum into five basic races: bicolor, caudatum, durra, guinea and kafir and ten intermediate races consisting of all combinations of the five basic races taking two at time. Based on this classification broomcorn belong to the bicolor race. Contemporary classifications consider it as Sorghum bicolor (L.) Moench, ssp. bicolor, race bicolor, working group nervosum-kaoliang (Dahlberg, 2000).

Broomcorn is a classic example of industrial use of sorghum, since its panicle has only one use as a raw material for brooms (Dahlberg and Wolfrum, 2011). Although domestication of sorghum in Africa is well documented (Dogget, 1988; Kimber, 2000), domestication of broomcorn remains rather uncertain. General opinion is the broomcorn evolved simultaneously by repeated selection for long fibers of the panicle throughout various regions worldwide. The origin of broomcorn in Europe is Mediterranean region and out of there it was spread in most of Europe (Berenji et al., 2011).

The world's largest collection of sorghum germplasm includes National Plant Germplasm System (USDA) with more than 42,000 samples, International Crop Research Institute for the Semi-Arid Tropics (ICRISAT) with over 36,000 samples, Chinese Agricultural Science Academy National Seed Bank (CASANSB) with over14,000samples (Reddy et al.,2008). These gene banks generally include all races and their derivatives with in Sorghum bicolor.

Serbia broomcorn breeding program was started more than 60 years ago in the Institute of Field and Vegetable Crops Novi $\mathrm{Sad}$, and during that period collection of over 450 samples was compiled. Based on the genetic constitution and geographic origin of this collection, it can be considered as the world broomcorn germplasm collection (Sikora, 2005). The core of the 54 genotypes which include $68-100 \%$ of the basic collection variability was separated and become the base for broomcorn breeding program (Sikora and Berenji, 2008).

A successful breeding program depends on the available germplasm with wide genetic divergence. Assessment of genetic distance among genotypes is main criterion for 
selection of parental combinations in segregating populations (Van Becelaere et al.,2005) and germplasm classification into heterotic groups in hybrid creating (Menz et al.,2004). Genetic divergence of germplasm can be perceived in terms of pedigree, geographical origin, agro-morphological trait sand molecular markers (Melchinger, 1999). Assessment based on pedigree due to the limited information related to specific genotypes is not of ten correlated with the overall variability of the germplasm (Fufa et al., 2005). Divergence of different sizes, genetic constitutions and sorghum collections geographic origins with usage of agromorphological markers was estimate earlier (Grenier et al., 2001a; Grenier et al., 2001b; Geleta et al.,2006; Aruna and Audilakshmi, 2008; Kumar et al., 2010). Although these markers are limited in number and influenced by the environmental conditions (Van Beuningen and Busch, 1997), they generally reflect genetic differences among genotypes in a good manner.

A landrace is a dynamic population(s) of a cultivated crop that has a historical origin, a distinct identity and lacks formal crop improvement. They are considered as locally adapted and environmental conditions may have a substantial impact on their main characteristics. The genetic diversity in landraces represent management processes and indigenous knowledge guiding farmer practices (Camacho Villa et al., 2005; Islam et al., 2014). Characterization of landraces is essential for their further utilization in breeding programs.

Broomcorn is a small scale alternative crop with regionally oriented production, and experimental information about this production is rare, so some references cited in this paper was older in date. To our best knowledge, except our previous studies of world broomcorn germplasm (Berenji, 1990, 2000; Sikora, 2005; Sikora and Berenji, 2008; Ikanovic et al., 2013; Glamoclija et al., 2015) this is first study concerning broomcorn landraces.

The main objectives of this study was to determine quantitative traits corresponding variability of South-East European (SEE) broomcorn landraces, and association among individual traits, so the most favorable accessions with the best agro-morphological and technological traits, which was not part of existing collection, could be included in the breeding program.

\section{MATERIALS AND METHODS}

Plant material: The most important agro-morphological quantitative features of 28 broomcorn landraces originated from SEE were analyzed. The region of this material is located within the geographic coordinates $42^{\circ} 10^{\prime}-48^{\circ} 70^{\prime} \mathrm{N}$, $17^{\circ} 80^{\prime}-24^{\circ} 60^{\prime} \mathrm{E}$ and it includes parts of the territories of Serbia, Hungary, Croatia, Romania and Bulgaria. Material includes locally adapted broomcorn landraces that has been maintained on individual farm over many years and each of them was developed under specific agro-climatic conditions and are associated with traditional farming systems (Table 1, Fig. 1).

Table 1. List of broomcorn accessions examined in the study.

\begin{tabular}{llll}
\hline Code & Description & IFVCNS ${ }^{\text {accession }}$ & Origin \\
\hline 1 & NS-BP/CL-12 & SO 001 & Serbia \\
2 & NS-BP/CL-4M & SO 002 & Serbia \\
3 & NS-BP/CL-6 & SO 012 & Serbia \\
4 & NS-BP/CL-8 & SO 019 & Serbia \\
5 & NS-BP/E-3905 & SO 020 & Serbia \\
6 & Csehoszlovák & SO 025 & Hungary \\
7 & Osztrak & SO 026 & Hungary \\
8 & Torda & SO 050 & Serbia \\
9 & Mezokovacshazi & SO 074 & Hungary \\
10 & Aradac 1 & SO 252 & Serbia \\
11 & Aradac 2 & SO 253 & Serbia \\
12 & LP 2/89 & SO 429 & Hungary \\
13 & LP 4/89 & SO 431 & Bulgaria \\
14 & LP 5/89 & SO 432 & Bulgaria \\
15 & LP 7/89 & SO 434 & Hungary \\
16 & LP 9/89 & SO 436 & Croatia \\
17 & LP 13/89 & SO 440 & Bulgaria \\
18 & LP 14/89 & SO 441 & Croatia \\
19 & LP 15/89 & SO 442 & Romania \\
20 & LP 17/89 & SO 444 & Bulgaria \\
21 & LP 19/89 & SO 446 & Bulgaria \\
22 & CL-2-MM-3 & SO 510 & Croatia \\
23 & CL-2K & SO 511 & Croatia \\
24 & LP 1/98 & SO 586 & Romania \\
25 & Paracin & SO 594 & Serbia \\
26 & Despotovac & SO 595 & Serbia \\
27 & DBK 36 & SO 699 & Romania \\
28 & VVM 131 & SO 700 & Romania \\
\hline a Institute of Field and Vegetable Crops Novi Sad, Serbia
\end{tabular}

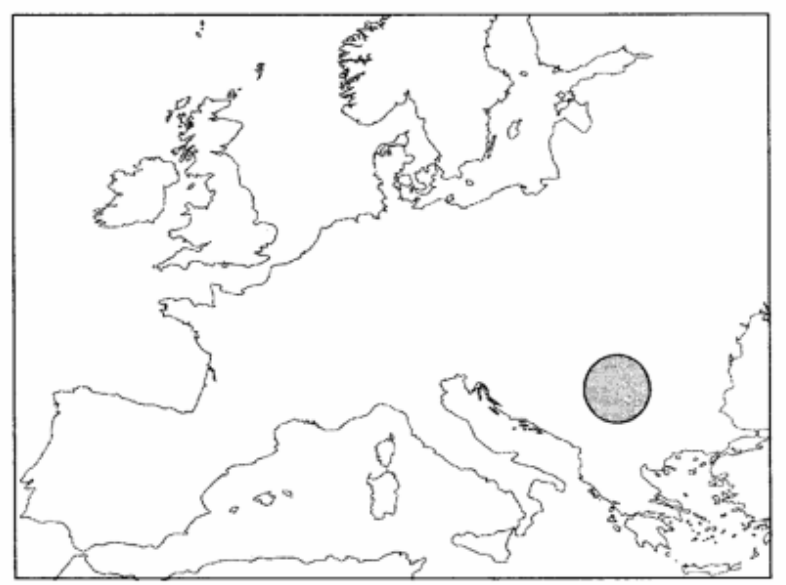

Figure 1. Region of origin of broomcorn landraces examined in the study. 
Table 2. Mean precipitation $(\mathrm{mm})$ and temperature $\left({ }^{\circ} \mathrm{C}\right)$ for site of Backi Petrovac, BP, Serbia.

\begin{tabular}{lcccc}
\hline Year & \multicolumn{3}{c}{ Precipitation $(\mathbf{m m})$} & Temperature $\left({ }^{\circ} \mathbf{C}\right)$ \\
\cline { 2 - 4 } & $\mathbf{X}$-III & IV-IX & X-IX & 19.7 \\
\hline 2002 & 157 & 347 & 504 & 18.2 \\
2005 & 365 & 552 & 917 & 19.2 \\
2006 & 229 & 445 & 674 & 19.0 \\
$1985-2010$ & 259 & 352 & 611 & \\
\hline
\end{tabular}

Field trials, experimental setup and climatic conditions: Field trials were set up at the site of Backi Petrovac $\left(45^{\circ} 20^{\prime} 32^{\prime \prime} \mathrm{N}, 19^{\circ} 40^{\prime} 55^{\prime \prime}\right.$ E, altitude $\left.82 \mathrm{~m}\right)$ on molisol in 2002 , 2005 and 2006 (Table 2 ). Elementary-two-row plots were 10 $\mathrm{m}$ long. Plant spacing was $0.7 \mathrm{~m}$ among rows and $0.1 \mathrm{~m}$ among plants within rows and total area of each plot was $14 \mathrm{~m}^{2}$. Plants within a plot, $10 \mathrm{~m}$, served as a replications. From each plot, five plants, was selected for analysis. Manual harvest was carried out by the technology of late harvest in physiological stage of ripe grain (Berenji and Sikora, 2002, Popovic, 2010, Sikora et al., 2015).

During the three year preceding crop was soybean, winter plowing was done to $30 \mathrm{~cm}$ soil depth in November and planting was completed between April 21st and 28th. Fertilization included application of $550 \mathrm{~kg} \mathrm{ha}^{-1}$ of mineral fertilizers NPK (8:16:24) along with autumnal tillage and 250 $\mathrm{kg} \mathrm{ha}^{-1}$ NPK (15:15:15) before seeding. The experiments was carried out under conventional tillage. The crops were kept free from weeds and insects according to best agricultural techniques.

The average air temperature during the growing season for the region in which the experiments were performed is $19.0^{\circ} \mathrm{C}$. With average temperature $19.2^{\circ} \mathrm{C}$ the year 2006 was equal to the long-term average, while 2002 with the average of $19.7^{\circ} \mathrm{Ccan}$ be considered as above average hot year, and 2005with the average of $18.2^{\circ} \mathrm{C}$ as cold year (Table 2, Fig. 2a). Average winter moisture supply for the reference site amounts $259 \mathrm{~mm}$ and the average rainfall for the growing season $352 \mathrm{~mm}$, what is $611 \mathrm{~mm}$ in total. In that respect, the 2006 with $674 \mathrm{~mm}(229 \mathrm{~mm}$ during winter and $445 \mathrm{~mm}$ for growing season) was the long-term on average level. 2002 with $157 \mathrm{~mm}$ of precipitation during winter and $347 \mathrm{~mm}$ during growing season and total of $504 \mathrm{~mm}$ can be considered was dry, and 2005 with total moisture supply of $917 \mathrm{~mm}$ (365 $\mathrm{mm}$ on winter and $552 \mathrm{~mm}$ on growing season) was wet year. Meteorological data in Table 2 and Figure 2 were obtained from official weather stations Hydro-meteorological Service of Serbia (http://www.hidmet.sr.gov.rs) located close to the experiment field.

Measurement of agro-morphological and technological traits: Measurements of components of plant height was usage of the measuring stick were first performed at selected plants. Plant height (PHG) represent height from the ground to the tip of the main panicle and stalk height (SHG) from the ground to the upper node. Based on different height components Berenji (1990) distinguished the American dwarf, European dwarf and traditional tall broomcorns. Length of the panicle (PLG) was calculated as difference between PHG and SHG and included length between upper node and base of fiber or peduncle length (PDL) and length of the fiber from the base to top or fiber length (FLG). Length of the top leaf sheath (LSL), Panicle exsertion (PEX) was calculated as difference between peduncle length and flag leaf sheath length. Panicles with peduncles of $15 \mathrm{~cm}$ were detached by hand and dried in a dryer.

(a)

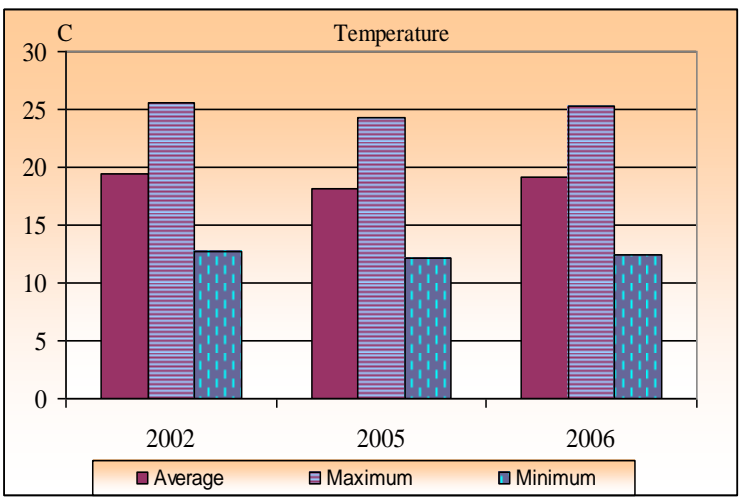

(b)

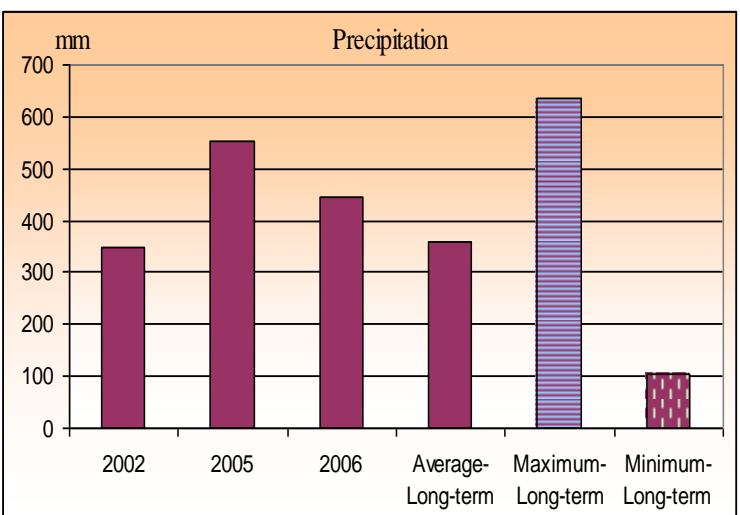

Figure 2. (a) Total precipitation ( $\mathrm{mm})$, and (b) average temperature $\left({ }^{\circ} \mathrm{C}\right)$ for growing season.

After drying of individual panicles the certain yield components, weight of unthreshed (UPW) and threshed (TPW) panicle after threshing grain was measured in the laboratory with the technical scale. Grain weight per panicle 
(GWT) was calculated as difference between UTP and TPW. Threshed panicle ratio (RAN) was calculated as the ratio of threshed panicle to the grain per panicle multiplied by 100 . Broomcorn panicle quality parameters was include the number of fibers per panicle (NOP), and that was determined by counting. The coefficient of fiber fineness (FFI) was expressed as the ratio of the peduncles mass and the total peduncle length per panicle multiplied by 1000 . Mijavec (1980) called peduncles the thready-like when their coefficient of fineness was below 250, thin among 250-500, thick in range of 500-1000 and rough above 1000, arguing that the technological aspect optimum is $400-600$, actually $0.4-0.6 \mathrm{~g} \mathrm{~m}^{-1}$.

Data analysis: Descriptive statistical parameters such as mean value, minimum and maximum values, standard deviation (SD) and coefficient of variation (CV) were used to describe the agro-technological traits of SEE broomcorn landraces collection. The fixed effect two-way analysis of variance (ANOVA) was performed to evaluate the magnitude of main factors effect and corresponding interactions. Non- parametric correlations among test traits represented by Spearman's rank correlation coefficients were computed and displayed as heat-map diagrams. The genotype-by-trait biplot (Yan and Rajcan, 2002) was used for studying relationships among traits across the landraces groups. All data analysis were done with the R software (R Development Core Team, 2012).

\section{RESULTS}

Variation among accessions: The measures of central tendency (means and range) and dispersion (SD and CV) parameters for broomcorn quantitative traits are presented in Table 3.

Mean value for PHG was $221.8 \mathrm{~cm}$ with range of 115.3 to $357.8 \mathrm{~cm}$, for SHG 124.2 with range of 37.8 to $269.6 \mathrm{~cm}$, for PLG $97.7 \mathrm{~cm}$ with range of 66.2 to $118.4 \mathrm{~cm}$, for PDL 30.1 $\mathrm{cm}$ with range of 15.4 to $46.4 \mathrm{~cm}$ and for FLG $67.8 \mathrm{~cm}$ with range of 43.1 to $86.9 \mathrm{~cm}$. PEX range from -25.4 to $2.2 \mathrm{~cm}$ with mean value of $-13.6 \mathrm{~cm}$ and the only one accession

Table 3. Summary table describing quantitative traits in 28 broomcorn accessions.

\begin{tabular}{llrrrrr}
\hline Trait & Code & \multicolumn{1}{c}{ Mean } & \multicolumn{1}{c}{ Min } & \multicolumn{1}{c}{ Max } & \multicolumn{1}{c}{ SD } & CV (\%) \\
\hline Plant height $(\mathrm{cm})$ & PHG & 221.8 & 115.3 & 357.8 & 66.0 & 29.8 \\
Stalk height (cm) & SHG & 124.2 & 37.8 & 269.6 & 68.8 & 55.4 \\
Panicle length (cm) & PLG & 97.7 & 66.2 & 118.4 & 16.1 & 16.5 \\
Peduncle length (cm) & PDL & 30.1 & 15.4 & 46.4 & 9.5 & 31.6 \\
Fiber length (cm) & FLG & 67.8 & 43.1 & 86.9 & 16.7 & 24.6 \\
Flag leaf sheath length (cm) & LSL & 43.5 & 38.7 & 51.9 & 5.7 & 13.2 \\
Panicle exsertion (cm) & PEX & -13.6 & -25.4 & 2.2 & 9.2 & 66.1 \\
Unthreshed panicle weight (g) & UTP & 71.2 & 50.0 & 97.7 & 23.5 & 32.9 \\
Threshed panicle weight (g) & TRP & 23.4 & 13.7 & 33.5 & 8.1 & 34.6 \\
Grain yield per panicle (g) & SWG & 47.8 & 31.0 & 77.4 & 20.4 & 42.7 \\
Threshed panicle ratio (\%) & RAN & 34.1 & 20.7 & 48.1 & 10.1 & 29.4 \\
Fiber number per panicle & FNO & 59.3 & 45.1 & 73.5 & 10.4 & 17.6 \\
Fiber fineness [(g m $\left.{ }^{-1}\right)$ x 1000] & FFI & 509 & 400 & 613 & 119.1 & 23.4 \\
\hline SD & & & & & &
\end{tabular}

SD standard deviation; CV coefficient of variation;

Table 4. Two-way ANOVA of the quantitative traits for 28 broomcorn accessions. MS tested with respective mean square error term.

\begin{tabular}{|c|c|c|c|}
\hline Trait & $\mathbf{G}$ & $\mathbf{Y}$ & GxY \\
\hline Plant height $(\mathrm{cm})$ & $58248.7 * *$ & $36112.4 * *$ & $1261.1^{* * *}$ \\
\hline Stalk height $(\mathrm{cm})$ & $66944.1 * *$ & $13758.3 * *$ & $1419.2 * *$ \\
\hline Panicle length $(\mathrm{cm})$ & $1901.1^{* *}$ & $5522.3 * *$ & $354.2 * *$ \\
\hline Peduncle length $(\mathrm{cm})$ & $813.9 * *$ & $595.1^{* *}$ & $81.1^{* *}$ \\
\hline Fiber length $(\mathrm{cm})$ & $2360.7 * *$ & $3927.8 * *$ & $341.8 * *$ \\
\hline Flag leaf sheath length $(\mathrm{cm})$ & $209.2 * *$ & $272.4 * *$ & $24.2 * *$ \\
\hline Panicle exsertion $(\mathrm{cm})$ & $753.9 * *$ & 109.6 & $91.8 * *$ \\
\hline Unthreshed panicle weight (g) & $2107.6^{* *}$ & $29773.3 * *$ & $849.8 * *$ \\
\hline Threshed panicle weight $(\mathrm{g})$ & $304.7 * *$ & $3249.4 * *$ & $113.1 * *$ \\
\hline Grain yield per panicle (g) & $2581.5^{* *}$ & $14470.7 * *$ & $669.0 * *$ \\
\hline Threshed panicle ratio (\%) & $1003.1 * *$ & $398.5^{* *}$ & $187.2 * *$ \\
\hline Fiber number per panicle & $785.2 * *$ & 192.4 & $170.7 * *$ \\
\hline Fiber fineness $\left[\left(\mathrm{g} \mathrm{m}^{-1}\right) \times 1000\right]$ & $43771.5 * *$ & $68896.5 * *$ & $1004022.3 * *$ \\
\hline
\end{tabular}

\footnotetext{
$* \mathrm{p}<0.05 ; * * \mathrm{p}<0.01 ; \quad$ G genotype, Y year, GxY genotype-by-year interaction
} 
(Mezokovácsházi) with positive value. The largest variation was found for PEX and SHG with $66.1 \%$ and $55.4 \%$. Maximum values for yield components was 2.0 to 2.5 times greater than minimum.

Yield components ranged in interval 50.0 to $97.7 \mathrm{~g}$ for UTP, 13.7 to $33.5 \mathrm{~g}$ for TRP and 31.0 to $77.4 \mathrm{~g}$ for $\mathrm{SWG}$ respectively. Average RAN were $34.1 \%$ with ranged from $20.7 \%$ to $48.1 \%$. CV for yield parameters ranged from $29.4 \%$ to $42.7 \%$ for RAN and SWG, respectively. For fiber quality parameters maximum values was 1.5 to 1.6 times greater than minimum for FNO and FFI respectively. FNO ranged from 45.1 to 73.5 with mean value of 59.3 and FFI ranged from 400 to 613 with mean value of $509\left(\mathrm{~g} \mathrm{~m}^{-1}\right)$.

Combined ANOVA across years (Table 4) indicated that mean square values were highly significant $(P<0.01)$ for all analyzed traits, except for the environmental effect on PEX and FNO. On average, genotype main effect $(\mathrm{G})$ was most important source of variation accounting for $65.1 \%$ of the total variance. Year main effect (E) averaged over all the traits accounted for $13.0 \%$, while genotype-by-environment interaction $(\mathrm{G} \times \mathrm{E})$ was $20.8 \%$ of the total variance.

Association among quantitative traits: The Spearman's rank correlations calculated for quantitative traits for three experimental years was visualized by colored heat maps for 2002 (Fig. 3a), for 2005 (Fig. 3b) and for 2006 (Fig. 3c).

Positive significant $(P<0.01)$ rank correlation in the $0.8-1.0$ range for the 2002 was demonstrated between following pairs of traits: PHG-SHG, PDL-PEX and UTP-SWG. Positive significant $(P<0.01)$ rank correlation in the $0.8-1.0$ range for 2005 were observed between the PHG-SHG, SHG-SWG, PLG-FLG, PDL-PEX, FLG-TRP, FLG-RAN and UTP-SWG, and negative significant rank correlations between the SHGRAN and SWG-RAN.

For the 2006 a positive significant $(P<0.01)$ rank correlation in the 0.8-1.0 range was observed between the PHG-SHG, PLG-FLG, PDL-PEX and UTP-SWG. The same significant rank correlations for all three years were observed between PHG-SHG, PDL-PEX and UTP-SWG.

Multivariate analysis of accessions quantitative traits: Multivariate analysis was used as a tool for relations understanding among quantitative traits and accessions. For 2002 (Fig. 4a) the PCA1 axis in the biplot explained $36.8 \%$ and PCA2 explained $23.1 \%$ of the total variation of the analyzed data. For 2005 (Fig. 4b) it was 51.1\% for PCA1 and $16.5 \%$ for PCA2 and for 2006 (Fig. 4c) it was $40.7 \%$ for PCA1 and $20.7 \%$ for PCA2, respectively.

Based on the position of the traits across the 28 accessions in biplot for 2002 (Fig. 4a), for 2005 (Fig. 4b) and for 2006 (Fig. 4c), three groups of accessions could be clearly defined. Traits with shorter distance to origin not well explained in the primary (i.e., PC1 vs. PC2) biplot in all three years was LSL and FNO. Accessions generally had low variation for these traits which represents group one. Group two include PHG, SHG, PDL, PEX, SWG and PEX and group three include
PLG, FLG, TRP, RAN and FFI. Group one and two was located on the upper right quadrant of PCA1 and positively correlated, while group three was situated in the positive quadrant of PCA1 and in negative correlations with groups one and two. Traits with in individual groups was in positive correlations.
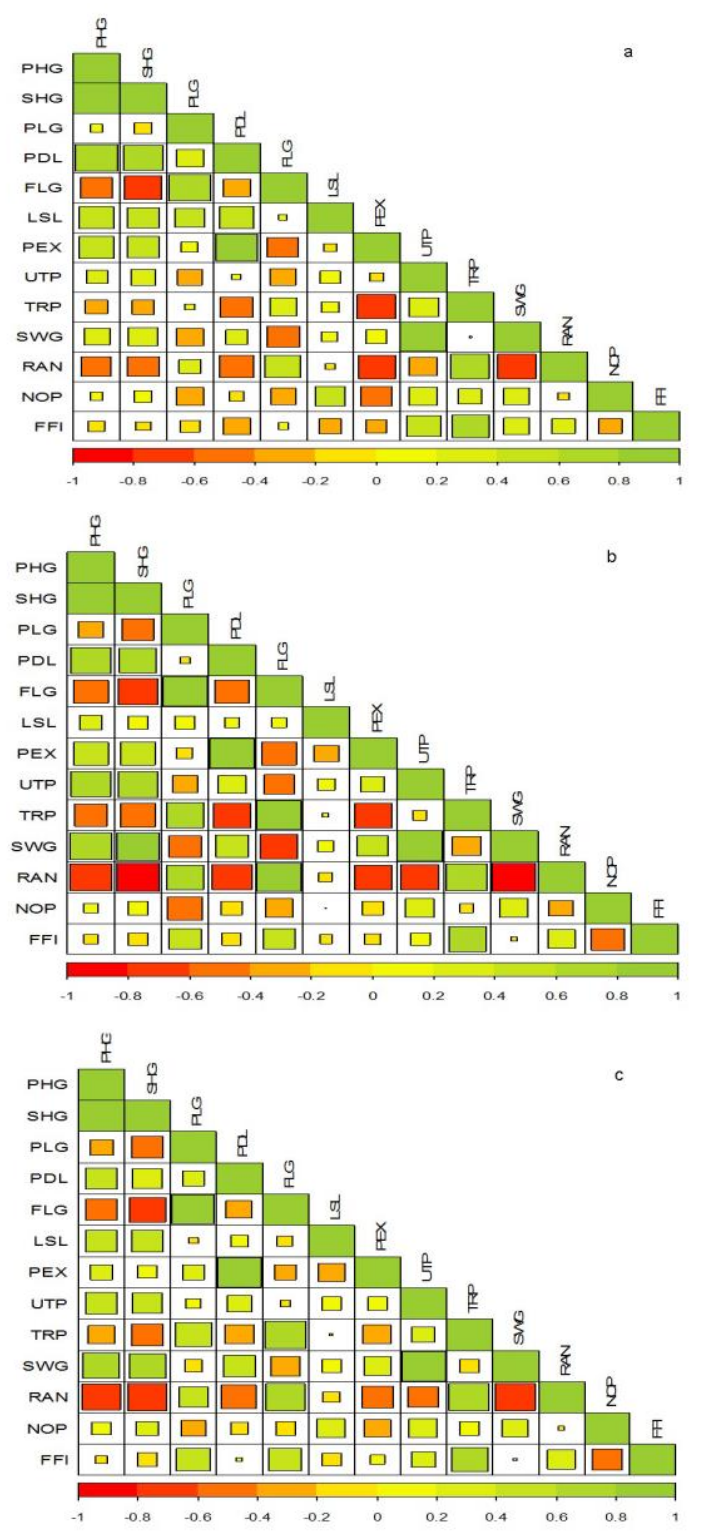

Figure 3. A heat-map of the Spearman nonparametric rank correlations for quantitative traits among 28 examined broomcorn landraces for 2002 (a), 2005 (b) and 2006 (c). The legend on the right side depicts the correlation color scale.

The details for the traits are given in Table 3 .

(a) 


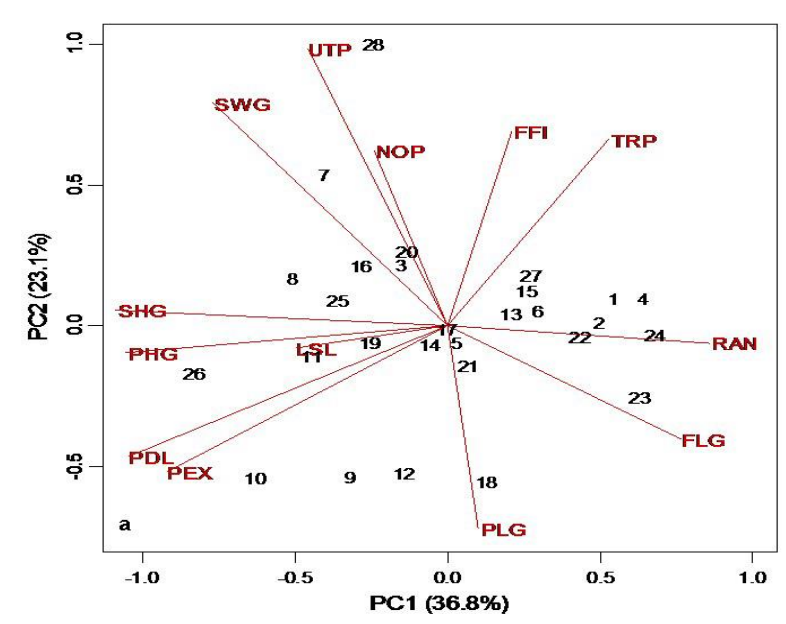

(b)

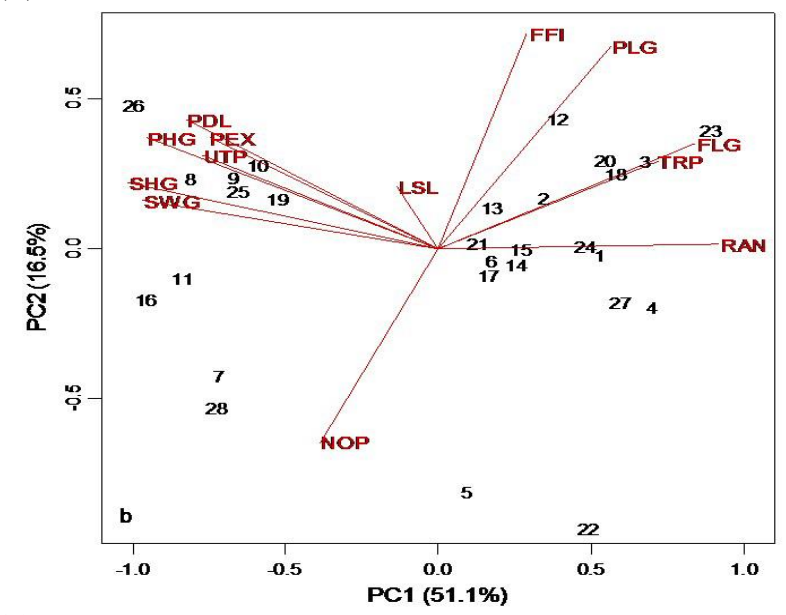

(c)

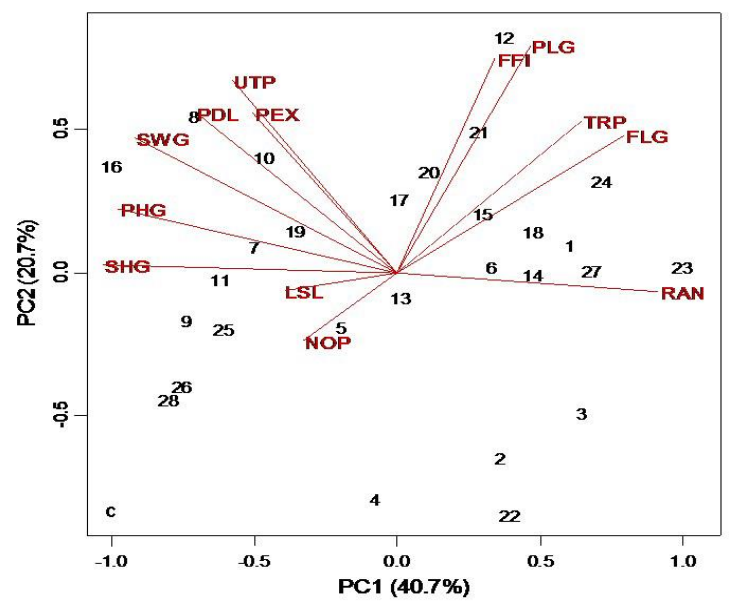

Figure 4. Biplots for 2002 (a), 2005 (b) and 2006 (c) of 28 broomcorn landraces accessions analyzed for 14 quantitative traits.

The details for the traits are given in Table 3 and the details for accessions are given in Table 1.

\section{DISCUSSION}

Biplot origin represented average values for all analyzed traits and the distance from biplot origin to the accession was a measure of how it differs from the average (Yan and FregeuReid, 2008). Accession with long vectors had extreme levels for one or more quantitative traits and they may be useful in breeding program. Of 28 landraces 18 (64.3\% of accession) had vector lengths shorter than $50 \%$ of the longest genotype vector for all three years, and they were less interesting as a source of useful genes for breeding program. During three years, 9 accession $(4,7,8,9,11,18,25,26$ and 28$)$ had longer vectors and they represented $32.8 \%$ of most promising breeding material of the total 28 landraces. Four accessions 1, 2,10 and 24 (14.3\% of accession) had longer vector for 2002 and 2006, respectively. For 2005 and 2006, respectively, three accessions 16, 22 and 23 (10.7\% of accessions) had vector longer than $50 \%$ of the longest genotype vector for that year. Accessions 5 and 3 had longer vectors for 2005 and accessions 12 and 27 for 2006 which represented $7.6 \%$ of the total 28 landraces (Fig. 4a-c).

The material for the trial included broomcorn landraces which were planted and maintained for long period in specific conditions of SEE sub-regions. Quantitative traits variability and association were determined to estimate possibility for including examined accessions in existing broomcorn germplasm.

According to Narkhede et al. (2000) and Kadam et al. (2001) geographic origin had no substantial influence on genetic diversity of sorghum germplasm. Early studies with broomcorn (Quesenbery and Will, 1948; Berenji, 1990) and the another types of sorghum (Showemimo, 2007, Rao et al., 2011) have suggested that the influence of year and genotype by year interaction in expression of quantitative traits are significant. Although certain proportion of the total variation is due to environment and interaction, substantial proportion of the total variation for most quantitative traits due to the genotype in our trials indicate possibility for yield improving and panicle quality through implementation of accessions in the breeding programs. Favor to this refer earlier determined broad sense heritability of $98 \%$ for PHG and SHG was by Berenji (1990), and broad sense heritability for all other traits in range of 57\% for LSL to 86\% for FLG (Sikora, 2005).

Variation among accessions: Although some earlier studies of sorghum sp. germplasm based on morphological characteristics suggested relative low variation in comparison with other crops (Morden et al., 1989, Ollitraut et al., 1989, Aldrich et al., 1992); however, Hamrick and Godt (1997) reported higher variation within sorghum than in other selfpollinated species. Same authors refer about 53\% divergence due to variation within forms, $14 \%$ due to variation among forms and only $11 \%$ due to variation between origin. Among all cultivated sorghum, the highest variation was found within bicolor race and lowest within kafir race (Dje et al., 2000; 
Grenier, 2001a; Menza et al., 2004). As a main reason why only few landraces are present in existing broomcorn collection. Berenji et al. (2011) refers surprisingly narrow variability of SEE landraces or local forms.

Salk height (60\%) and panicle length (12\%) (Umakantha et al., 2002) had predominant influence on plant height variation in Sorghum genus. Based on components of height substantial proportion (68\%) of accessions belongs with dwarf type and only $32 \%$ of them represent traditional tall broomcorn. The initial material for selection of long fiber sorghum was sweet sorghum with diffuse panicles tall up to $3 \mathrm{~m}$ (Rothgeb, 1916). In the beginning, tall broomcorn plant were harvested by cutting the whole plant at ground level and stalks of the plant were tied together to form traditional brooms. Contemporary large scale of agronomic practices prefer dwarf broomcorn varieties from which only the panicle portion of the plant is harvested and fibers of these panicles serve as a raw material for commercial production of wooden handle brooms (Berenji et al., 2011). In our trials, 9 tall accessions originated from Serbian and Hungarian sub-regions. This can be explain by the fact that broomcorn planting and old fashioned homemade brooms making in this sub-regions had longer tradition. After expansion of broomcorn broom industry in the middle of XX century and establishment of scientific programs on broomcorn technology improvement (Szeged in Hungary and Novi Sad in Serbia), dwarf material was spread to the other sub-regions, where panicles were used only for industrial brooms manufacturing (Nedelcheva et al., 2007).

Broomcorn industry requires elastic fiber with length in range of $30-60 \mathrm{~cm}$. Substantial proportion of accessions $(71 \%)$ had fiber longer than $60 \mathrm{~cm}$ which is too long even for cover part of the broom and surplus parts represent waste in broom production. Handmade production of untypical brooms can be the main reason for spontaneous selection on too long fiber in landraces.

Panicle exsertion represent difference between flag leaf sheath length and peduncle length. Negative value reflect panicles that have not exerted from flag leaf so whole peduncle and part of fibers is enclosed in the flag leaf sheath. Panicle exsertion have substantial influence on manual harvesting of panicles, which is easier if panicles are exerted. Substantial proportion of accessions (71\%) had extremely negative exsertion while only one (Mezökovácsházi) had the positive value and 7 others (25\%) had panicles acceptably exerted up to $-10 \mathrm{~cm}$. Similar to the findings of Sikora (2005), flag leaf sheath length is trait with low variation which means that panicle exsertion is predominantly influenced by peduncle length. As a main reason for high variation of peduncle length within the same field Berenji (1990) suggested micro-environmental conditions. He recorded higher peduncle length variability on poor stand and for low plant emergence. In drought conditions during blooming and flowering period internodes were shorter and exsertion was extremely negative. Although Berenji et al., (2011) referred that there is no or little difference between dwarf types as compared to standard broomcorns in respect to the flag leaf sheath length, in the case of this study accessions with long peduncle and exsertion close to zero is predominantly standard type.

Mann and Washburn (1930) referred that first quality broomcorn fibers must be round, straight, elastic and fully branched at the top third of their length. Almost half of accessions $(43 \%)$ had a thick fibers with fineness below 0.5 $\mathrm{gm}^{-1}$ and fiber number per panicle over 60 . Fiber number per panicle is less important trait in comparison with fiber length and its important is due influence on fiber fineness (Mijavec, 1980). Broom producers consider that higher fiber number means thinner and more elastic fibers.

For this study unthreshed panicle weight ranged from 50.0 to 97.7 g. Previous study of the broomcorn germplasm showed significantly higher variability for the yield in range of 14.8 to $114.0 \mathrm{~g}$ per unthreshed panicle (Sikora 2005). Main reason for this difference is that basic germplasm included low yielding genotypes with some interesting quantitative or qualitative characteristics like high fiber number or tolerance to prevalent pests. In the beginning of broomcorn breeding improvement program main goal was creation of variety with high unthreshed panicle weight. Later, higher weight of threshed panicle is pointed as a target for second breeding cycle. This was reached through increasing of threshed panicle ratio and results with few high yielding commercial varieties (Mijavec 1980). Of all accessions only one (DBK 36) had threshed panicle ratio over $30 \%$, and for substantial proportion of the accessions (82\%) threshed panicle ratio range $20-30 \%$ which was in average with the value of this trait in basic germplasm.

Association among traits and biplot analysis: Correlations of broomcorn quantitative traits were observed for potential effort in obtaining desired yield and quality of panicles through breeding. Similar to our earlier findings (Berenji, 1990; Sikora, 2005), there was a significant positive correlation between PHG -SHG and PDL-PEX in examined material. Due to manual harvest of panicles, breeding strategies should be focused on dwarf type landraces with panicle exsertion close to zero. Among the studied accessions, there were several from Bulgaria with stalk height below 100 $\mathrm{cm}$ and panicle exsertion up to $-10 \mathrm{~cm}$ (LP 13/89, LP 17/89 and LP 19/89), that could serve as a good start point for future breeding program. Sikora and Berenji (2000) referred that determination of LSL is due to non-additive gene effects and determination of PDL due to additive gene effects. LSL is most stable traits so positive PEX can be obtained only with long peduncle. There was a moderate negative correlations between PDL and FLG which means that first class medium length fibers were connected with medium $(30-40 \mathrm{~cm})$ length peduncle.

For breeding strategies the most important correlations between traits are connected with yield (Berenji and Sikora, 
2002). Results of the analysis refers significant positive correlations between UTP-SWG which are in negative correlations with RAN. In broomcorn production seed is valuable by-product (Berenji et al., 2011) but main product is high quality RAN. Approach to increasing TRP yield could be through increasing FNO, RAN and FFI respectively. Determination of the best accessories through a multivariate analysis for specific purposes in the aspect of yield and quality would be the most suitable approach.

While correlation matrix described only relationships between two traits biplot describe relationships among all traits (Yan and Rajcan, 2002). Variables positioning on the opposite side of the PC1 axis can be useful for determining a selection criteria. For increasing yield of TRP lower SWG and higher PLG and RAN would be desire. High value of FFI can be obtain through selection of accessions with high PLG and FNO.

If accession origin is considered, it is evident that Serbian, Croatian, Romanian and Hungarian accessions with high within group variability were distributed across the biplot, while Bulgarian accessions (LP 4/89, LP 5/89, LP 13/89, LP 17/89 and LP 19/89) were distributed close to biplot center which pointed to their low variability within the group. In this group combination of natural selection and selection performed by farmers lead to above average $(>100 \mathrm{~cm}$ ) PLG with over $70 \mathrm{~cm}$ FLG.

Conclusion: The examined SEE broomcorn landraces showed exceptional variability that can be exploited for improving yield and panicle quality of new varieties. All of them will be included in existing broomcorn germplasm and several accessions of different origin with exclusive trait profile for yield components (Osztrak, Torda, LP 9/89 and Despotovac) and panicle quality (NS-BP/CL-12, LP 2/89, LP $14 / 89$, CL-2K and LP 1/98) will be useful as parents in the breeding process. High-yielding landraces had higher grain yield per panicle, but showed significantly lower threshed panicle ratio. Panicle yield was in positive correlation with amount of grain per panicle. Traits association with fiber quality was threshed panicle ratio, fiber number per panicle fiber length. Landraces with best fiber quality showed high threshed panicle ratio and had high number of medium length fibers. Fiber quality is directly correlated with fiber number per panicle. Different behavior of individual accessions in specific conditions show that further investigation of environmental influence on expression of individual traits in broomcorn germplasm should be done.

Acknowledgments: Investigations presented in this papers are part of the project, TP 31073, financed by the Ministry of Education and Science of Republic of Serbia.

\section{REFERENCES}

Abubaker, B.M.A., Y.S. En, S.G. Cheng, and M. Alhadi. 2014. Impact of different water harvesting techniques on soil moisture content and yield components of sorghum. Pak. J. Agri. Sci. 51:779.788.

Aldrich, P.R., J. Doeble, K. Schertz and A. Stec. 1992. Patterns of allozyme variation in cultivated and wild Sorghum bicolor. Theor. Appl. Genet. 85:451-460.

Aruna, C. and S. Audilakshmi. 2008. A strategy to identify potential germplasm for improving yield attributes using diversity analysis in sorghum. Plant Genet. Res. 6:187194.

Berenji, J. 1990. Variability and interrelationship of characters in various broomcorn (Sorghum bicolor (L.) Moench) genotypes. Ph.D. Diss., Faculty of Agriculture, University of Novi Sad, Serbia.

Berenji, J. 2000.Genetic resources in broomcorn, p.10. In: K. Konstantinov (ed.), Abstracts of the $17^{\text {th }}$ EUCARPIA International Conference on Maize and Sorghum Genetic and Breeding at the end of the $20^{\text {th }}$ Century. Belgrade, 49 June, 2000.

Berenji, J. and V. Sikora. 2002.Trends and achievements in broomcorn breeding. Cereal Res. Commun. 30:81-88.

Berenji, J. and J. Dahlberg. 2004. Perspectives of sorghum in Europe. J. Agron. Crop Sci. 1905:332-338.

Berenji, J., J. Dahlberg, V. Sikora and D. Latkovic. 2011. Origin, history, morphology, production, improvement and utilization of broomcorn (Sorghum bicolor (L.) Moench) in Serbia. Econ. Bot. 65:190-208.

Camacho Villa, T.C., N. Maxted, M.A. Scholten and B.V. Ford-Lloyd. 2005.Defining and identifying crop landraces. Plant Genet. Resour. 3:373-384.

Dahlberg, J. 2000. Classification and characterization of sorghum, p.99-130. In: C.W. Smith and R.A. Frederiksen (eds.), Sorghum: Origin, history, technology, and production. John Wiley \& Sons Inc, New York.

Dahlberg, J. and E. Wolfrum. 2011. Compositional and agronomic evaluation of sorghum biomass as a potential feedstock for renewable fuels. J. Biobas. Mater. Bioener. 4:1-7.

Dje, Y., M. Heuertz, C. Lefebvre and X. Vekemans. 2000. Assessment of genetic diversity within and among germplasm accessions in cultivated sorghum using microsatellite markers. Theor. Appl. Genet. 100:918925.

Fufa, H., P.S. Baenziger, B.S. Beecher, I. Dweikat, R.A. Graybosch and K.M. Eskridge. 2005.Comparison of phenotypic and molecular marker-based classifications of hard red winter wheat cultivars. Euphytica 145:133146.

Geleta, N., M.T. Labuschagne and C.D. Viljoen. 2006.Genetic diversity analysis in sorghum germplasm 
as estimated by AFLP, SSR and morpho-agronomical markers. Biodiver. Conserv. 15:3251-3265.

Glamoclija, Dj., S. Jankovic, V. Popovic, V. Filipovic, J. Kuzevski and V. Ugrenovic. 2015. Alternative crops in conventional and organic growing system. IPN Belgrade. 1-345. 20-40.

Grenier, C., P.J. Bramel-Cox and P. Hamon. 2001a. Core collection of sorghum: I. Stratification based on ecogeographical data. Crop Sci. 41:234-240.

Grenier, C., P. Hamon and P.J. Bramel-Cox. 2001b. Core collection of sorghum: II Comparison of three random sampling strategies. Crop Sci. 41:241-246.

Hamrick, J.L. and M.J.W. Godt. 1997. Allozyme diversity in cultivated crops. Crop Sci. 37:26-30.

Harlan, J.R. and J.M.J. de Wet. 1972. A simplified classification of cultivated sorghum. Crop Sci. 12:172176.

Ikanovic, J, V. Popovic, V. Trkulja, Lj. Zivanovic, Z. Lakic and S. Pavlovic. 2013. Morphological characteristics of the interspecies hybrid between sorghum and Sudan grass under intensive nitrogen nutrition. Genetika 45:3140.

Islam, M.S., M.A.B. Mia, M.R. Das, T. Hossain, J.U. Ahmed and M.M. Hossain. 2014. Sex phenology of bitter gourd (Momordica charantia L.) landraces and its relation to yield potential and fruit quality. Pak. J. Agri. Sci. 51:651658.

Kadam, D.E., F.B. Patil, T.J. Bhor and P.N. Harer. 2001. Genetic diversity studies in sweet sorghum. J. Mahar. Agric. Univ. 26:140-143.

Kimber, C.T. 2000. Origins of domesticated sorghum and its early diffusion to India and China, p.3-98. In: C.W. Smith and R.A. Frederiksen (eds.), Sorghum: Origin, history, technology, and production. John Wiley \& Sons Inc, New York.

Kumar, A.A., B.S.V. Reddy, M. Blummel, S. Anandan, Y.R. Reddy, C.R. Reddy, P.S. Rao and P.S. Reddy. 2010.Onfarm evaluation of elite sweet sorghum genotypes for grain and stover yields and fodder quality. Anim. Nutr. Feed Techn. Vol:69-78.

Mann, J.A. and R.S. Washburn. 1930. Broomcorn growing and handling. U.S. Department of Agriculture Farmers' Bulletin 1631.

Melchinger, A.E. 1999.Genetic diversity and heterosis, p.99118. In: J.G. Coors and S. Pandey (ed.), The Genetics and Exploitation of Heterosis in Crops. ASA-CSSA, Madison, WI.

Menza, M.A., R.R. Kleina, N.C. Unruha, W.L. Rooney, P.E. Kleina and J. Mulleta. 2004. Genetic diversity of public inbreds of sorghum determined by mapped AFLP and SSR markers. Crop Sci. 44:1236-1244.

Mijavec, A. 1980. Evaluation of broomcorn panicle quality. Bilten za hmelj i sirak 35:37-46.
Morden, C.W., J. Doebley and K.F. Schertz. 1989. Allozyme variation among the spontaneous species of Sorghum section Sorghum. Am. J. Bot. 76:247-255.

Narkhede, B.N., J.H. Akade and V.R. Awari. 2000. Genetic diversity in rabi sorghum local types. Jour. Mahar. Agric. Univ. 25:245-248.

Nedelcheva, A.M., Y. Dogan and P.M. Guarrera. 2007. Plants traditionally used to make brooms in several European countries. J. Enthom. Ethnomed. Vol:3:20.

Ollitrault, P., M. Arnaud and J. Chantereau. 1989. Polymorphisme enzymatique des sorgos. II. Organisation genetique et evolutive des sorghos cultives. L'Agro. Trop. 44:211-222.

Quesenbery, G.R. and R.R. Will. 1948. Broomcorn. New Mexico College Agriculture and Mechanical Arts, Agricultural Extension Services, State College, New Mexico.

Popovic, V. (2010). Influence of Agro-cultural and agroecological practices on seed production of wheat, maize and soybean. Ph.D. dissertation, University of Belgrade, Faculty of Agriculture, Zemun, Belgrade Serbia, 1-145, 62-65.

R Development Core Team R. 2012. A Language and Environment for Statistical Computing. R Foundation for Statistical Computing. Vienna, Austria http://www.rproject.org, ISBN 3-900051-07-0.

Rao, P.S., P.S. Reddy, A. Rathore, B.V.S. Reddy and S. Panwar. 2011. Application GGE biplot and AMMI model to evaluate sweet sorghum (Sorghum bicolor) hybrids for genotype $\mathrm{x}$ environment interaction and seasonal adaptation. Ind. J. Agric. Sci. 81:438-444.

Reddy, B.V.S., A.A. Kumar, P.S. Reddy and M. Elangovan. 2008. Sorghum germplasm: diversity and utilization, p.153-169. In: Sorghum genetic enhancement: research process, dissemination and impacts. ICRISAT, Patancheru, Andhra Pradesh, India.

Rooney, L.W. and R.D. Waniska. 2000. Sorghum food and industrial utilization, p.689-729. In: C.W. Smith and R.A. Frederiksen (ed.), Sorghum: Origin, history, technology, and production. John Wiley \& Sons Inc, New York.

Rothgeb, B.E. 1916. Standard broom corn. U.S. Department of Agriculture Farmers' Bulletin No. 958.

Showemimo, F.A. 2007. Grain yield response and stability indices in sorghum (Sorghum bicolor (L.) Moench). Commun. Biom. Crop Sci. 2:68-73.

Sikora, V. and J. Berenji. 2000. Estimation of Hybrid vigor in broomcorn. p. 7. In: K. Konstantinov (ed.) Abstracts of the $17^{\text {th }}$ EUCARPIA International Conference on Maize and Sorghum Genetic and Breeding at the end of the $20^{\text {th }}$ Century. Belgrade, 4-9 June, 2000.

Sikora, V. 2005. Variability in germplasm of broomcorn (Sorghum bicolor (L.) Moench). Ph.D. Diss., Faculty of Agriculture, University of Novi Sad, Serbia. 
Sikora, V. and J. Berenji. 2008. Core collection of broomcorn (Sorghum bicolor (L.) Moench), p.216-219. In: B. Kobiljski (ed.), Proceedings of Breeding 08 Conventional and Molecular Breeding of Field and Vegetable Crops. Institute of Field and Vegetable Crops, Novi Sad.

Sikora, V., J. Berenji, V. Popovic, M. Brdar-Jokanovic and L. Maksimovic. 2015. Accumulation and distribution of NPK in above ground parts of grain sorghum and maize in intensive production. Agric. Forest. 61:223-230.

Umakantha, A.V., R. Madhusudhana, S. Kaul and B.S. Rana. 2002. Genetic diversity studies in sorghum. Inter. Sorg. Mill. News 43:31-33.
Van, B.G., E.L. Lumbbers, A.H. Paterson and P.W. Chee. 2005.Pedigree-vs. DNA marker-based genetic similarity estimates in cotton. Crop Sci. 45:2281-2287.

Van,B.L.T. andR.H. Busch. 1997.Genetic Diversity among North American Spring Wheat Cultivars: I. Analysis of the Coefficient of Parentage Matrix. Crop Sci. 37:570579.

Yan, W. and J. Fregeu-Reid. 2008. Breeding line selection based on multiple traits. Crop Sci. 48:417-42.

Yan, W. and I. Rajcan. 2002. Biplot evaluation of test sites and trait relations of soybean in Ontario. Crop Sci. 42:1 $1-20$. 